\title{
Stanisław Patek and aspects of russian law enforcement in the Kingdom of Poland, 1875-1914
}

Keywords: Stanislaw Patek, Russian law enforcement, Combat Organization of the Polish Socialist Party, Revolution 1905, Russian penal system, Judiciary and Polish lawyers

Stanisław Patek (1866-1944) was a prominent lawyer in the Polish Kingdom in the years 1904-1911. He had links with Masonic, socialist and liberal groupings, and was involved in a diverse range of socio-political activities. During the revolutionary turmoil of 1905 he established contacts with Józef Piłsudski and soon entered Piłsudski’s inner-circle of collaborators. After World War I, Patek abandoned his professional legal practice for the world of diplomacy and politics. He was delegated by Piłsudski to attend the Paris Peace Conference in February 1919. During the Polish-Soviet War, he was the Minister of Foreign Affairs (16 December 1919 - 9 June 1920). He was Poland's official representative in Tokyo (1921-1926) and Moscow (1927-1932), and the Ambassador to Washington in 1933-1936. He was appointed to the Senate of the Republic of Poland by the President in 1936, where he sat on the Senate's Foreign Affairs Committee until 1939. ${ }^{2}$

The most intensive period of Stanisław Patek's activity as a lawyer came in 19041907. They were years of revolutionary ferment in Russia and the Polish Kingdom, and he was concentrated on defending young revolutionaries before the tsarist courts. He had a good deal of sympathy for them, their ideals, and their opposition

1 This study was produced as part of the Ministry of Science and Higher Education funded research project no. NN108108434: "Stanisław Patek and his times - a biography of the lawyer and diplomat Stanisław Patek (1866-1944)".

2 More in: M. Gmurczyk-Wrońska Stanisław Patek - preliminary biographical sketch: state of research, sources, research problems, "Dzieje Najnowsze" 3 (2007), pp. 3-25. 
to tsarism. ${ }^{3} \mathrm{He}$ articulated his feelings in a well-known text titled Jak umierali (How They Died), which was a shocking account of his experience as a defence counsel of revolutionaries sentenced to death. ${ }^{4} \mathrm{He}$ wrote about them: "revolution's desperate men", "individuals, for whom humdrum everyday life was not enough, who above all came to love the ideals which informed their activity." 5 Patek also wrote that a lawyer who accompanied a client, whom he failed to defend against the death penalty, is cursed with an experience which cannot be erased from his memory. "Such visits are horrible. It was as if a miserable prison cell would change into a funeral parlour."' He always met with those of his clients who were sentenced to death just before their execution. He considered it his duty, his obligation as a lawyer and as a man.

Stanisław Andrzej Radek, a member of the Combat Organization of the Polish Socialist Party [Organizacja Bojowa Polskiej Partii Socjalistycznej, abbreviated OBPPS] wrote about Patek:

The Combat Organization has a particular debt of gratitude to Patek because he was the initiator of numerous wonderful episodes in its history. Under Patek's influence, as a result of talking to him, many combatants who were court martialled, were transformed from ordinary soldiers into heroes. Without exaggeration, one could say that hundreds of people owed their lives to Patek, and hundreds of people owed their liberty to him. Patek's law office became a political defence centre. Patek's audacious speeches, candour and dignity, with which he would argue his case in court, won him the respect and recognition of the authorities as well. They believed in the legitimacy of his mission because they were compelled to do so. Patek the barrister, whole-heartedly dedicated to defending political offenders and helping victim-participants of the mass movements, did not veer off the straight and narrow road of legality, and did not come into conflict with the binding law. ${ }^{7}$

Stanisław Patek was defence counsel in several political trials. During the martial law period in the Polish Kingdom, the regime's civilian opponents were typically tried by court martial. A defence counsel's brief was extremely difficult in that it tended to be confined more to laying bare in word and attitude the iniquities of the Russian judicial system. His task was often no more than a desperate and unsuc-

3 Patek also defended revolutionaries who were part of the Soviet power apparatus after 1017. Throughout his life, Patek subscribed to the principle that everyone had the right to preach one's own views, but he was critical of Bolshevism and the Communist system in the USSR. He wrote about this in his reports from Moscow, see S. Patek, Raporty i korespondencja z Moskwy (1927-1932), ed. M. Gmurczyk-Wrońska, Warsaw 2010.

4 S. Patek, Jak umierali, in: Journal of Pavilion X, ed. A. Kozłowski, H.J. Mościcki, Warsaw 1958, pp. 294-304.

5 ibid, pp. 297-298.

6 ibid, p. 23.

7 S.A. Radek, Rewolucja w Warszawie 1904-1909, Warsaw 1937, pp. 375-377. 
cessful attempt to save lives. Lawyers and revolutionaries alike were aware of this fact. An SDKPiL member wrote in a letter at the time of Marcin Kasprzak's trial that: "as the prosecutor states, defence in a court martial is useless." ${ }^{8}$ However, many political offenders would often nominate Patek as their defence counsel, even in seemingly hopeless cases. ${ }^{9}$ Patek mainly became famous as the defence counsel of PPS, SDKPiL, and later, Bolshevik revolutionaries. His name - as a barrister - was to appear very frequently in the press. In particular, "Gazeta Sądowa Warszawska", "Kurjer Warszawski", "Kurjer Codzienny" and "Czerwony Sztandar" carried reports on the trials in progress and on their outcomes. The cases of Marcin Kasprzak (19041905), Stefan Okrzeja (1905) and Józef Montwiłł (also known as Mirecki - in 1908), were among Patek's most publicised defeats.

The trial of Marcin Kasprzak ${ }^{10}$ was one of the first and most important political trials, for Patek as the defence counsel. Kasprzak was sentenced to death and executed on 8 September 1905. He was one of the organizers of socialist groupings in Poznań; in 1888 he co-organized the Polish Socialist-Revolutionary Party Proletariat (called the 2nd Proletariat), connected with the SDKPiL as from 1904. He was charged under article 1469 part II of the criminal law and under article 279 of the martial law for armed resistance to 'representatives of the authorities', murder, and illegal opposition to the regime in the ranks of the SDKPiL. Kasprzak's case was hopeless. Patek's line of defence was to question Kasprzak's physical state, and therefore he demanded a medical opinion. When the presiding judge pointed out that a couple of years earlier, while under arrest, Kasprzak "has already been under observation in hospital and he escaped from there!", Patek rejoindered that: "Russia is unhappy great power indeed, if it cannot supervise one madman ... The possibility to escape is not an argument. I think that a powerful country like Russia is well able to keep one man under lock and key." ${ }^{\prime 1}$ The trial was adjourned but Kasprzak was not subjected to psychiatric examination. The trial ended in defeat for the defence.

The trial and execution of Stafan Okrzeja ${ }^{12}$, a member of the Combat Organization of the PPS, was among the more shocking events of that era. Okrzeja was accused of membership of a revolutionary party, the murder of a Russian policeman and of planting a bomb at the police station in the Praga district in Warsaw. He was 18 years old and was tried by court martial under the notorious article 279 of the martial code, which recognised only one punishment - death. In his case for the defence

8 AAN, the SDKPiL [the Social Democrat Party of the Kingdom of Poland and Lithuania], Main Board, 9/II-11, W. Matuszewski's letter, Cracow, 3 July 1904, p. 18.

9 AAN. See the rich correspondence on this topic in the collections of the SDKPiL, Main Board, 9/II-11; 9/II-7.B.

10 More in: Z. Paterczyk, Marcin Kasprzak i jego "sprawa". Anatomia funkcjonowania niesłusznego oskarżenia, Warsaw-Poznań 1985.

11 "Czerwony Sztandar", no. 19, p. 7.

12 G. Daniłowski [Władysław Orwid], Stefan Okrzeja. Życiorys, Warsaw 1910; K. Paszkowski, Stefan Okrzeja, Łódź 1948; Pamięci Stefana Okrzei. W dwudziesta piąta rocznice jego stracenia, Warsaw 1930; L. Dubacki, Stefan Okrzeja. W stulecie śmierci, "Przegląd socjalistyczny" no. 4-5/2005 July-December 2005. 
delivered before the District Court Martial in Warsaw, Patek stressed the idealistic views of Okrzeja, for whom socialism was a solution to people's problems. Patek accused the police of brutality during the events of January and February in Warsaw, and asked "is it truly the duty of the police to harass the incapacitated? ... The police that acts on the strength of its authority, the policemen who lost their heads and were guilty of cruelty, the policemen who triggered a cry of terror and thirst for revenge in Okrzeja's heart, it was they who are responsible for engendering Okrzeja's craving for the happiness of all people, for his reaching for a bomb and him becoming a terrorist in bloody protest against his oppressors at the cost of his own life." ${ }^{3}$ Patek first of all challenged the applicability of article 279 under which Okrzeja was to be tried. He argued that it was wrongful to bring charges under this article since it only applied to a time of war, in particular, its section 1 allowed for the application of some general criminal law regulations and not those of martial law. Patek went even further in his exegesis and critically analysed the martial code emphasising its excessively restrictive character and the absurdity of lumping together various offences to produce the charge of an offence against the state. He also pointed at the interpretative ambiguity and problems concerning the categorization of Okrzeja's criminal acts. The issues raised by Patek in his speech for the defence were connected with a sequence of complicated Russian regulations of criminal and martial law, which were undoubtedly one of crucial features of the tsarist system.

Patek also failed in his defence of the well-known revolutionary Józef Mirecki. ${ }^{14}$ Mirecki was an active member of the Combat Organization of the PPS. Having escaped from prison several times, he was arrested in 1907 and sentenced to death in 1908. After the delivery of Mirecki's sentence, Patek went to Governor-General Gieorgij Skałon " 15 "with a demand to allow an appeal against the sentence or to have the sentence commuted", to which he received the well-known answer "no, I can't. ... What would St. Petersburg say to that? Not allowed." 16 Adam Próchnik reported that Patek even sent several telegrams to St. Petersburg requesting a pardon for Mirecki. ${ }^{17}$ Mirecki’s

13 S. Patek, Obrona Okrzei. Streszczenie mowy obrończej w sprawie Okrzei, in: id, Ze wspomnień obrońcy, Warsaw 1937, p. 5.

14 More in: G. Daniłowski, Na stokach cytadeli (Józef Mirecki), Warsaw 1916; A. Próchnik, Józef Mirecki (1879-1908). Do biografii Józefa Mireckiego, in: A. Próchnik, Studia z dziejów polskiego ruchu robotniczego, Warsaw 1958, pp. 393-408.

15 Georgij Antonovicz Skałon (1847-1914) was of French descent (de Scalon). His family had Huguenot roots. Upon the abolition of the Edict of Nantes, the Scalons moved to Sweden and then to Russia. G. Skałon graduated from the Moscow Junker School and took part in Russo-Turkish war of 1877-1878. He came to the Kingdom in 1893 as a special assignments officer. He owed this function to Governor-General Josif Hurtze (they knew each other from the Turkish war). He was appointed Governor-General of Warsaw on 28 August 1905 and held that post until 1914. More in: A. Próchnik, Zamach na Skałona, in: Studia z dziejów polskiego ruchu robotniczego, pp. 450-492; also Ł. Chimiak, Gubernatorzy rosyjscy w Królestwie Polskim 1863-1915. Szkic do portretu zbiorowego, Wrocław 1999.

16 S. Patek, op. cit., p. 16.

17 A. Próchnik, Józef Mirecki (1879-1908), pp. 393-408. 
trial evoked interest beyond the Kingdom because Patek even received letters from the editors of German left-wing magazines requesting information about the trial. ${ }^{18}$

Patek met with Skałon several times in similar cases but one case was special. It was about commuting the sentences of two women - Zofia Owczarek and Kazimiera Ostrowska (of the SDKPiL) - who were sentenced to death for an attempt on Skałon's life. ${ }^{19}$ Patek wrote: "to whom should I go to prevent the death penalty being carried out? - I couldn't do anything but go to Skalon himself. I went ... (and) when I entered Skałon's office, I found him with a surprised but not gloomy look on his face: Do you come in 'my' case? - No, Governor, I am here because of Owczarek and Ostrowska." Admittedly, Skałon also tried to be firm in this case, but Pater succeeded in gaining the following assurance from him: "Be calm. I will not hang those old women." ${ }^{20}$ In the end, the death penalty was commuted to life imprisonment.

Stanisław Patek lived at 25 Królewska Street in Warsaw. There he also had his law office which was popularly called "the office" or "the other side". 21 There, frequently under Patek's tutelage, "dress rehearsals" of witnesses were held in preparation for their court appearances, and friendly doctors advised how the accused could "engender a fever or feign serious illness". ${ }^{22}$ Stefania Sempołowska ${ }^{23}$ wrote that the lives of the families of those held in custody were focused on "the office" where help and care for "prisoners of all political groups" was also organized. ${ }^{24}$ As the lawyer Leon Berenson ${ }^{25}$ was to write - "A large Polish Underground (resistance movement)"26

18 AAN, the KC PZPR, 699/5, without date and signature.

19 A. Próchnik, Zamach na Skałona, p. 467. The famous "donations for a bomb for Skałon" set in motion preparations for the coup. The whole plan was drawn up by Mieczysław Mańkowski, an activist of Proletariat I, later the PPS, and its execution was entrusted to Wanda Krahelska (a member of the Combat Organization of the PPS, an artist, a journalist), Zofia Owczarek (1887-1940, the Combat Organization of the PPS, later known as the Revolutionary Faction) and Albertyna Helbert. This elaborate plan proved to be nothing but amateurish. The bombs that were devised failed in their purpose. Skałon survived and Owczarek was arrested. Ostrowska, who was already in prison with a death sentence hanging over her, also admitted to taking part in plot.

20 S. Patek, op. cit., pp. 20-21.

21 L. Berenson, Królewska 25, in: S. Sempołowska, W więzieniach, Warsaw 1960, pp. 364-365.

22 ibid, p. 373.

23 Stefania Sempołowska (1869-1944), a teacher, involved in socio-political activity in both the tsarist period and subsequently, in independent Poland. After 1918 she took part in the exchange of political prisoners between Poland and the USSR.

24 S. Sempołowska, op. cit., p. 95.

25 Leon Berenson (1882-1941) defended Felix Dzherzhynsky (Dzierżyński) during the revolution. He succeeded in securing the release of Bolesław Wieniawa-Długoszowski in Moscow in 1918 with Dzherzhynski's help. He defended Adam Pragier and Norbert Barlicki in the Brest-Litovsk trials of 1931-1933. Berenson died in the Warsaw Ghetto built by the Germans during World War II.

26 L. Berenson, Królewska 25, p. 363; id, Z sali śmierci. Wrażenia obrońcy politycznego, Warsaw 1928. 
sprang up there. Both Berenson and another well-known lawyer and jurist - Stanisław Emil Rappaport ${ }^{27}$ - wrote about Stanisław Patek's devotion to defending prisoners and his involvement in helping their families in any way that he could.

\section{The revolutionary turmoil of 1905-1907}

Lawyers had plenty of work during the revolution of 1905-1907 in the Polish Kingdom. The number of prisoners was constantly increasing. In January 1906, there were 4509 political prisoners under lock and key. ${ }^{28}$ This was the result of intensifying tsarist repression against an increasingly radical society. Russia's defeat in the war with Japan activated various centres of disaffection in the tsarist empire. Liberals were the closest to Patek's heart. He belonged to the Progressive and Democratic Union established in 1904 (called "Pedecja", with Aleksander Świętochowski as its chairman). The central plank of this party's liberal programme was autonomy for the Kingdom with a Constituent Assembly in Warsaw. ${ }^{29}$ Liberal parties in Warsaw were not numerous, and tended to attract writers and journalists, lawyers, barristers and doctors. They were mostly alumni of Warsaw University and the Main School in Warsaw. Members of this party remained in regular contact with Russian Liberals. Russian liberalism was not homogeneous; it attracted supporters of the Constitution and groupings seeking minor cosmetic changes to a political system that would keep the burgeoning bureaucracy in check. ${ }^{30}$

As far as the Polish Kingdom is concerned, researchers now stress the growth of numerous, usually inter-linked, multidimensional processes involving workers, national-emancipationists, socio-economic reformers and civil rights activists. ${ }^{31}$ The latter of these seem to have been of capital importance in relation to Patek's activity. They constituted a diversified panoply of views, all of which espoused an awareness of the Kingdom's backwardness in relation to Western Europe - not just economic, but also political in terms of political institutions and civil liberties.

The 1905 revolution exposed the abyss separating the Kingdom's society in terms of its needs, expectations and demands, and the highly bureaucratic tsarist police state. Above all, the Kingdom demanded changes - from those aimed purely at improving living standards to those postulating autonomy or independence. The pressure for change came from both organized groups, including the workers' movement its organization and party, and the ferment in the ranks of the broadly understood

27 S.E. Rappaport, Moje czasy adwokackie, "Palestra" no. 2, 1958, pp. 17-18. Rappaport was the author of works such as: Międzynarodowa przyszłość Polski, Warsaw 1916; Projekt kodeksu karnego dla ziem polskich, Warsaw 1916 and Ostatnie chwile S. Patka, "Kurier Codzienny", no. 105, 1949.

28 Quoted after J. Zdrada, Historia Polski 1795-1914, Warsaw 2005, p. 777.

29 More in: T. Stegner, Liberałowie Królestwa Polskiego 1904-1915, Gdańsk 1990.

30 More in: M. Smoleń, Rosyjska inteligencja liberalna i radykalna w XIX i na początku XX wieku, Kraków 2010.

31 Dziedzictwo rewolucji 1905-1907, ed. A. Żarnowska, A. Kołodziejczyk, A. Stawarz, P. Tusiński, Warsaw-Radom 2007, Introduction, p. 8. 
intelligentsia. Demonstrations and strikes became part and parcel of the Kingdom's daily routine which symbolized resistance and the need for reforms. In 1905, the Kingdom was gripped by an enthusiastic belief in the possibility of victory over the Russian system. The streets "were flooded with people ready for anything", chanting slogans like: "Long live Socialism", "Long live Poland! Down with the Tsar", "Long live independence"; or those addressed to the Tsar's troops - "Brothers come over to us." 32 This series of events was called "a living machine". ${ }^{33}$ Magdalena Micińska is right in saying that "the revolution of 1905-1907 was the first manifestation of modernity on Polish territory. The mass-membership parties that began to form at the end of the 19th century - Socialists and National Democrats - unexpectedly gained a laboratory where they could test their boldest conceptions. And they exploited those chances uninhibitedly." ${ }^{34}$ Poles in the Kingdom demanded above all the constitutional and political rights that had evolved in Western Europe; they demanded general elections and the right to participate in representative institutions, personal liberty, freedom of speech and of the press, the right of association and gathering, independence of the courts and a myriad other demands. However, there were differences in determining a common approach to Russia. There was also the problem of autonomy or independence. The PPS propagated full independence, the National League a broad autonomous programme. Neither the SDKPiL nor the PPS "Proletariat" parties subscribed to any independence slogans; they linked the Polish revolutionary movement to the Russian one.

The problem of autonomy was broadly reflected in the contemporary press. Polish demands for autonomy were linked to the reform processes in evidence in Russia, in particular in regard of the differing Russian party attitudes in this matter. Autonomy was not a uniformly understood concept: for some it was to be the introduction of the Polish language in schools, courts and offices (both the Russian language and the Polish language were allowed in government offices), for others it was to be a separate Sejm (parliament) for the Kingdom, and still others postulated the accession of the Kingdom to "the future Slavonic federal state." ${ }^{35}$

The tsarist authorities applied diverse tactics in response to those developments in the Kingdom - beginning with the intensified legislative activities stimulated by martial law and progressing to amnesty for political prisoners (the Tsar's Ukase of 21 October 1905 meant partial amnesty which was severely criticized ${ }^{36}$ ) and a temporary thaw in the draconian regime. Every few days the authorities would issue

32 ibid, p. 106.

33 This expression was frequently used by “Gazeta Sądowa Warszawska”, e.g., no. 1, 6 January 1906, p. 8 (criminal chronicle).

34 M. Micińska, Inteligencja na rozdrożach 1864-1918, Warsaw 2008, p. 143; this publication constitutes vol. 3 of Dzieje Inteligencji Polskiej do roku 1918, ed. J. Jedlicki, Warsaw 2008.

35 J.J. Litauer, Autonomia Królestwa Polskiego w programach rosyjskich stronnictw politycznych, “Gazeta Sądowa Warszawska”, no. 21, 26 May 1906, pp. 332-333.

36 H.C. [probably Henryk Cederbaum], Znaczenie prawne amnestji, "Kurier Warszawski", no. 307-308, 7 November 1905, pp. 2-3. 
press announcements and declarations. One of Governor-General Gieorgij Skałon's announcements stated: "The latest events show that the liberty given to the citizens in reality changes into rampant lawlessness ... Brutal violence, unfortunately supported by the majority, has gripped trade, industry, railway traffic, leaving thousands of people without earnings, causing panic among peaceful citizens. People recklessly abandon their jobs to form crowds that follow the leaders of different parties ..."37 By this announcement, Skałon banned outdoor public meetings, including religious processions, under sanction of armed intervention. ${ }^{38}$

The Russian penal system in the late 19th and early 20th century against the European background ${ }^{39}$

Western views on the penal systems of 18th and 19th century Europe, and the need of criminal law reform, were driven by the nostrums and values that swept in with the Enlightenment. In the 19th century they were the outcomes of political struggles between Liberals and Conservatives, which carried over into criminal law, utilitarianism, positivism, and especially romanticism which espoused individualism and human rights. The 19th century brought in the process of creating new criminal and civil laws which harmonised with the progressive achievements of the new era in Western Europe. One of its characteristics was the tendency to moderate penalties and respect the rights of individuals (including freedom of thought). ${ }^{40} \mathrm{In}$ practice, particularly in regard of criminal law and its principles and enforcement, depended on the given country's political and legal system, or its lack.

The deliberations of contemporary jurists growing out of sociological determinism, the theory of evolution and anthropology, obviously headed in the direction of humanising the given country's legal system, and also in the direction of moderating the scale of penalties and showing greater sensitivity in the treatment of prisoners, thereby linking those issues with morality and humanitarian ideals. Ideas of liberty and equality before the law endorsed by the Enlightenment and the French Revolution, together with liberal and democratic slogans and the emerging powerful workers' movement, spilled over into legislation not only in Western Europe, because they also gained supporters among the subjects of absolutist systems, particularly among the nations fighting for their freedom and liberty.

Because of the social character of criminal acts, penal issues, unlike civil issues, were of a public character. Admittedly this principle was extant in jurisprudence in the past, but in the 19th century everybody who was not found guilty, enjoyed the presumption of innocence and hence enjoyed the assured protection of the law

37 Skałon's announcement on 22 October (6 November) 1905, "Kurier Warszawski", 7 November 1905, no. 307-308, p. 2.

38 ibid.

39 Those issues were presented by E. Kaczyńska in: Człowiek przed sądem. Aspekty przestępczości w Królestwie Polskim 1815-1914, Warsaw 1982; Ludzie ukarani. Więzienia i system kar w Królestwie polskim 1815-1914, Warsaw 1989.

40 More in: E. Kaczyńska, Ludzie ukarani, p. 13. 
of liberty. The corollary to this process was the introduction of court-appointed defence lawyers in court proceedings.

The Napoleonic Code of the Grand Duchy of Warsaw was still binding in the reconstituted Polish Kingdom after 1815, but the regime was gradually aligned with Russian law. This process was intensified after 1864. A characteristic feature of the Russian system was a very strict and absolute penal law based on a huge number of directives and acts (which were constantly modified).

The Code of the Main and Reformatory Punishments, which was introduced in Russia in 1866, was introduced in the Polish Kingdom, together with changes in the judiciary and the legal community as such, in $1876 .{ }^{41}$ This stringent penal Code allowed to bring even 10-year-olds before the courts. For crimes against the country (an attempt on the life of the Tsar, protests and harbouring wanted fugitives) and treason, the penalty was death or the loss of civic rights, penal servitude or exile. For example, the infamous article 99 instituted the death penalty for an attempt on the life of the Tsar and an heir to the throne; article 100 - the death penalty or penal servitude for aspiring to change "the ruling system" in Russia or in any country belonging to Russia; article 123 - penal servitude for attacks on police patrols, arms depots and railways; article 124 - penal servitude for belonging to banned associations; article 124 - penal servitude for taking part in conspiracies. ${ }^{42}$

This Code was subsequently repeatedly modified by further acts, regulations, amendments and supplements. In consequence, chaos frequently prevailed in the courts. All those circumstances together with the liberal tendencies within the ranks of the Russian elites, were the reasons why a working committee was set up in Russia in 1885 to produce a new Penal Code. After ten years, an eight-volume draft was produced, and in 1902 it was submitted to the Ministry of Justice. Its proposal to introduce suspended sentences or parole was something new to Russian law. However, it still included (like the previous directives), the death penalty for political offences (which had no equivalent in Europe), including acts against tsarism, the highest state authorities, or the state system. This Code was approved by the Tsar in 1903, but until World War I only the part concerning political offences was applicable (subject to special directives). ${ }^{43}$ In practice, the previous Code of the Main and Reformatory Punishments, together with the Court Martial Code, remained binding in the Kingdom. The Martial Code regulated all that related to war conditions and martial law. It was mainly invoked because of the existence of the field courts-martial in the Kingdom, but it was also permitted in peacetime. Usually, the Governor-General decided on when to apply it. Field courts-martial and the Court Martial Code with its infamous article 279, in practice blocked access to legal representation. The procedure was described by the legal journal "Gazeta

41 More in: E. Kaczyńska, Człowiek przed sądem; op. cit. Ludzie ukarani; A. Korbowicz, Sądownictwo Królestwa Polskiego 1876-1915, Lublin 1995.

42 H. C., Znaczenie prawne amnestii, pp. 2-3.

43 More in: E. Kaczyńska, Człowiek przed sądem, pp. 191-206; op. cit. Ludzie ukarani, p. 130. 
Sądowa Warszawska": "Delegated panels of five officers appointed by a garrison or a military unit commander at the request of the Governor-General, a general or a person in power, were called courts. The judges were not required to have any particular qualifications, any special or general education, or to be of any particular age. One condition was required though: those judges should - if possible - serve in the army no less than four years. In this 'court' there is neither public prosecutor nor defence lawyer; this trial is not preceded by either investigation or indictment; this 'court' sits in camera and its sentences are without right of appeal. There is no possibility of an appeal of last resort. The whole procedure of the 'court' is defined in six articles (1376-1381) of the court-martial bills ... We should presume that ... the authorities should apply the new law on the basis of article 279 of the military directive on penalties (murder, rape, robbery, arson) and on the basis of the Highest Ukase of the Governing Senate of 9 August 1878 (armed resistance and attacks on the army, the police and officials with murderous intent, grievous bodily harm and arson). The authorities should not bend the law. Obviously, this institution lacks the features of a court of law. It is an illegal institution. It is a governmental institution in which there is not even one norm that is evolved by reference to law and criminal procedure. Verily, it is a cancer in the national body politic without a binding Russian prototype in the statutes ... You would not find a model for the courts created by this new Russian act in any legislation in the world." 44 The same "Gazeta Sądowa Warszawska" also reported on Article 279 of the Military and Criminal Act: "This Article has made history. The growing revolutionary troubles and terrorist attacks in Russia had an influence on changing the article of this military act; its application has been stretched to such an extent that it has assumed state-wide significance. Under the Ukase of the Governing Senate of 9 August 1878, people accused of armed resistance to the authorities and attacking representatives of the army or the police while on duty, were tried by court martial as appropriate to wartime conditions, and punishment was prescribed under article 279 of the Military and Criminal Act if the offence was linked to murder, attempted murder, or grievous bodily harm. This is not the end of it. While passing the regulations of 14 August 1881 on measures to be taken to preserve public law and order, the supplement to article 279 of the Military and Criminal Act was a source of special prerogatives bestowed on Governors-General and Governors, whereby they acquired extraordinary powers of enforcement to maintain peace. Hence, civilians and soldiers alike found themselves subject to substantive military laws applicable in wartime, and to accelerated trial procedures with limited rights of defence typical of wartime conditions. Therefore, for example, upon being indicted, the accused had twenty-four hours to appoint a defence counsel, summon witnesses and state his case (article 1380 of the Military and Criminal Act). If witnesses refuse to take the stand, the accused may declare that they will bring the witnesses to court themselves, but not within

44 Mikołaj Kor. [probably pseudonym], Sądy polowe, “Gazeta Sądowa Warszawska”, no. 37, 15 September 1906, pp. 569-570. 
7 days, as in ordinary courts, but immediately upon the announcement of a negative decision (article 1383). Accepting or rejecting an appeal against the sentence of a court martial depends on the will of the district's commander-in-chief, who is empowered not to allow an appeal (article 1401). This is the most important aspect in court which never allowed an appeal only an appeal of last resort against a sentence to the main court martial. This applies not to just any kind of the sentences but mostly to death sentences." ${ }^{35}$ It should be noted that the courts martial applied article 279 of the Military and Criminal Act in the case of charges of attempts to break the Kingdom away from Russia, and overthrow the current system. ${ }^{46}$

Jan Kucharzewski wrote that the Russian system left many issues "unspecified", enabling the authorities to intervene in various areas without need to qualify the specific legal basis of their actions. ${ }^{47}$ This ostensible state of indeterminacy allowed the Tsar to extend the powers of high ranking officials to deliver the severest of sentences as they saw fit. That was so in the application of martial law in the Polish Kingdom. It was introduced or lifted in various districts in the Kingdom, depending on the scale of dissent. All other districts typically remained subject to increased security measures. ${ }^{48}$ Under the Tsar's Ukase of 24 th June 1905, the Warsaw Governor-General was granted rights which were basically "unrestricted powers of enforcement." ${ }^{49}$ Based on article 12 of this Ukase, the Governor-General was authorised to take extraordinary measures which exceeded his statutorily defined executive powers. Gieorgij Skałon was all for exercising the coercive powers that were vested in him. He took office in August 1905 and quickly made himself known as "the bloody enemy

45 Quoted after Kronika Kryminalna, "Gazeta Sądowa Warszawska", no. 1, 6 January 1906, p. 9.

46 Such information was contained in press reports the course of proceedings or only the verdicts of courts martial. For example, "Gazeta Sądowa Warszawska", no. 37, 15 September 1906, p. 579.

47 J. Kucharzewski, Od Białego Caratu do Czerwonego, vol. 1, Epoka Mikołaja I, Warsaw 1926, p. 50.

48 More in A. Próchnik, Rządy wojennych generat-gubernatorów w epoce stanu wojennego, in: Studia $z$ dziejów polskiego ruchu robotniczego, pp. 345-387. Próchnik stated that under the Tsar's Ukase of 24 June 1905, martial law was introduced in the city and county of Łódź. Martial law was introduced in the city and county of Warsaw on 23 August 1905. However, all ten provinces of the Polish Kingdom were under martial law on 10 November. Martial law was abolished on 1 December 1905 and re-imposed a few days later in the counties of Wołkowysk, Kalwaria, Władysławowo and Marianopol. On 21 December, this law was reintroduced in the Polish Kingdom and abolished in the provinces of Kielce, Lublin, Łomża, Płock, Radom, Siedlce and Suwałki on 11 October 1908. A state of emergency was maintained for one year. Initially it was imposed for six months in the provinces of Warsaw and Radom, but extended to a year in April 1909, and extended further in the following years. By 1914, it remained in force only in the province of Piotrków. The Governor-General was given special powers of enforcement. The tsarist authorities reintroduced martial law in the Kingdom at the beginning of the war (2 August 1914). Overall, martial law was imposed in 1906 and it was gradually lifted, place by place, by 1909 .

49 After Fiodor Berg's death in 1874, the Russian authorities closed down the governor's office and introduced the office of Governor-General (in Warsaw). He was given combined administrative and police powers with command of the Warsaw military district. Hence, the Governor-General had supreme power in the Kingdom. He was also empowered to issue "binding decisions", the right of arrest without giving a reason and the right to court martial civilians, as from 1879. Apart from that, court martial judges were subject to the Governor-General's control. 
of revolutionaries." He diligently followed Pyotr Stołypin's instruction - "to sentence to death without trial." 50 In November 1905, Skałon instructed his temporarilyappointed district governors-general to use the powers of enforcement under article 12 "to impose the death penalty without trial." ${ }^{11}$ In practice, only special committees heard those cases. Skałon's actions provoked Warsaw lawyers into taking strike action and filing a complaint in St. Petersburg in 1905. We do not know whether Stanisław Patek participated in these initiatives. It is also unclear whether this strike had any effect on the opinion of central authorities. ${ }^{52}$ However, we know that Sergei Witte, the Prime Minister, was critical of Skałon's actions and induced the Tsar to ban death penalties without proper trial on 5 January 1906. Admittedly, the ban was binding but summary death sentences continued to be occasionally delivered. From the literature, we know that the revolutionary period of 1905-1907 brought a sombre harvest of summary executions under the Governor-General's orders. Sentences were often pronounced by courts martial, that is military courts which dealt with civil cases during the states of emergency that were habitually declared. ${ }^{53}$

On 24 October 1906, Prime Minister Stołypin sent a circular letter instructing governors-general and district governors that: "In order to fight against the most dangerous aspects of the revolutionary movement in places where martial law or a state of emergency has been declared, under the most important orders of 1 and 2 September (under art. 1361/3), governors-general, district governors and officials empowered to court martial those whose guilt is so obvious that there is no need of investigation." 54

50 As from April 1906, Pyotr Stołypin was the Minister of the Interior, and in July 1906 became Prime Minister; he held that office till 1911. More in: L. Bazylow, Ostatnie lata Rosji carskiej. Rzady Stołypina, Warsaw 2008, chapter VI, Terror i kontrterror, pp. 135-166; J. Zdrada, op. cit., pp. 776-777.

51 A. Próchnik, Rządy wojennych generał-gubernatorów, p. 361.

52 This issue was only discussed at the plenary session of Department I of the Governing Senate in 1906. Opinions concerning Skałon's activities were divided. They ranged from the position that the Governor-General was responsible to the Tsar and nobody else, and thus the supervision of the Senate did not apply to him, and the complaint filed by lawyers could be ignored (if only because the aggrieved party did not file it), to the view that Skałon should address this issue, but on the basis of article 12. Voices that were critical of Skałon and his instructions that those deemed to be guilty should be court martialled, were few and far between. In 1908, the Polish lawyers' complaint about Skałon's activity was still under consideration in the Ministry of Justice, and only in 1909 was the first ruling of the General Assembly of the Senate, recognizing the legitimacy of Skałon's activity under article 12, was issued. A. Próchnik wrote more about it in Rządy wojennych generał-gubernatorów, pp. 372-374.

53 According to H. Kiepurska (Warszawa w rewolucji 1905-1907, Warsaw 1974, p. 327) 3 people were executed "in Warsaw in 1905, in 1906 - 47 people, 1907 - 127 people, 1908 - 184 people. Almost one thousand people in the Polish Kingdom were sentenced to death.” J. Zdrada, op. cit., p. 777, states that 343 death sentences were carried out in 1906, in 1907 - 124, and in 1908 - 184. The most important works on this topic are: Kodeks Karny rosyjski $z$ dnia 22 marca 1903 roku, translated into Polish by J. Krzymuski, A. Małkowski, J. Namiotkiewicz, Warsaw 1916; F. Kon, Sądy wojenne w Cytadeli, Warsaw 1915; A. Korbowicz, Sądownictwo Królestwa Polskiego; E. Kaczyńska, Człowiek przed sq̨dem; op. cit., Ludzie ukarani; H. Kiepurska, Adwokaci warszawscy w okresie rewolucji 1905-1907, Warsaw 1964, offprint from no. 2, 3 and 4 "Palestra".

54 “Gazeta Sądowa Warszawska”, no. 44, 3 November 1906, pp. 684-685. 
The criminal system in Russia and the Polish Kingdom, particularly martial law and the use of the death penalty, differed from Western European practices. If a state of emergency was introduced, it usually lasted a precisely defined period; however, parliaments decided on their imposition. Although the death penalty for severe crimes was maintained in most countries of Western Europe, opponents of its execution were extremely active. Such attitudes were also in evidence in Russia. Leo Tolstoy issued the brochures Do not kill in 1907 and I cannot be silent in 1908. ${ }^{55}$ Liberal groupings in Russia and St. Petersburg sought to broach this problem in public debate at the beginning of 20th century.

\section{The Judiciary and Polish lawyers}

The judiciary in the Kingdom had rich traditions dating back to the First Republic and the Napoleonic era. The legal community functioned as a corporation with its own well-developed professional self-government. This was liquidated after 1876.

In 1876, the tsarist authorities abolished Polish courts and extended the Russian judicial reform of 1864 to the Kingdom..$^{56}$ This came in tandem with direct Russian supervision and control of the Polish legal community and the liquidation of its professional self-government. Defence councils (composed of lawyers working at a given court) were also abolished. These had been self-governing bodies which were tasked with appointing lawyers; they had been chosen by lawyers. These councils were also allowed to function in Russia, but, for the most part, they did not develop in the way they had in Poland because of the lack of any long-standing legal tradition in Russia. In the Polish Kingdom, however, a Defence Commission was established in their place in 1876 (and operated until 1882), but this was no longer an independent self-governing body, because was dependent on the judiciary system's authorities.

Henryk Cederbaum, a well-known lawyer and jurist, wrote: "The Council, admitting a candidate to the bar, should duly consider a candidate's formal qualifications (diploma and work experience, etc.) as well as and his appropriate qualifications in terms of ethical standards. When the Judiciary Acts were introduced in the Polish Kingdom in 1876, defence councils were abolished because of the political conditions prevailing in the country and their duties were transferred to district courts." ${ }^{27}$ Lawyers were subordinated to the general assemblies of the district courts which appointed lawyers and also acted as professional disciplinary courts.

Russian officials occupied higher positions of authority while only lower ranking positions - barristers, solicitors, public notaries - were open to home-bred members of the legal profession. Poles could be lawyers after graduating from university or an institution of equal rank, with a law degree. They also had to undergo a 5-year

55 Quoted after: E. Kaczyńska, Ludzie ukarani, p. 201.

56 More in: H. Kiepurska, Inteligencja zawodowa Warszawy 1905-1907, Warsaw 1967, pp. 40-42; op. cit., Adwokaci warszawscy, pp. 11-12; A. Korbowicz, Sądownictwo Królestwa Polskiego.

57 H. Cederbaum, Adwokatura w Królestwie Polskim: luźne kartki, Warsaw-Kraków 1911, p. 65. 
"internship" at court, rising through the ranks "as a candidate, undersecretary, secretary, etc." or as lawyers' assistants. ${ }^{58}$ This system excluded non-Christians, which in practice meant people of Jewish extraction. Candidates had to be approved by the district courts and nominated by the Minister of Justice. Such nominations were rare in 1904. Following the reform, changes occurred in the legal community itself. Sworn lawyers replaced the old ranks of patrons, barristers and ordinary lawyers. Patek was a sworn lawyer. The title was awarded to the established members of the bar upon passing a Russian language exam.

The Warsaw Court Chamber was established as the Court of Appeal for the Polish Kingdom after 1876. The Kingdom was divided into ten judicial districts each corresponding to the size of a province. New courts were established in each of these districts - rural municipal courts and magistrates' courts in the cities, and Justice of Peace Assemblies (which brought together the judges of rural municipal and magistrates' courts) and district courts (one in each province). The Governing Senate in St. Petersburg was the Court of Appeal. There was no division into civil and criminal courts in the Kingdom. ${ }^{59}$

Unlike in Russia, lawyers in the Kingdom had very limited legal possibilities of setting up their own professional associations though they did try to organise themselves as informal groupings which met privately to exchange opinions and observations on the their professional practice and the system in which they had to operate in. Not being able to function formally as a chartered professional association, they worked in "institutions" of an economic nature such as the Commercial Section of the Trade and Industry Support Society, or the Sworn Lawyers' Assistance Fund (which operated as a financial self-help initiative). Unfortunately, from 1891, the public prosecutor of the Court Chamber or his deputy had the right to attend the Fund's meetings. Stanisław Patek belonged to what was called the Bar Consultancy of Sworn Lawyers as from November 1904. The Bar Consultancy offered free legal aid to poorer people. Its members worked at the Warsaw District Court where they had fixed rotas (typically in the afternoons). ${ }^{60}$ The Bar Consultancy sought to adopt more organized forms of activity vis-à-vis the tsarist authorities, if only in such matters as addressing memoranda and petitions to the Governor-General on reinstating the Polish language at least at the municipal level. ${ }^{61}$

Revolutionary events in the Russian Empire stimulated the legal community into action. Patek, along with Stanisław Posner, Henryk Konica, Tadeusz Strzembosz and Leon Papieski, was a member of the Polish delegation at the first meeting of the Polish-Russian legal community which was occasioned by the All-Russian

58 ibid, p. 62.

59 Quoted after: E. Kaczyńska, Człowiek przed sqdem, p. 206; for more on this topic see: S. Kutrzeba, Historia ustroju Polski w zarysie, vol. 3, Poznań 2001, p. 193; W. Miklaszewski, Rys organizacji władz sądowych. Zbiór praw i rozporządzeń Królestwa Polskiego, Warsaw 1881 and 1888.

60 The press reported on the activity of the Bar Consultancy; for example, see "Kurjer Codzienny", no. 30, 5 February 1905, p. 1.

61 H. Kiepurska, Adwokaci warszawscy, “The Bar” 2(74), pp. 14-15. 
Congress of Lawyers held in St. Petersburg in April 1905. The Polish side issued a statement, which emphasized the necessity to grant the Kingdom its autonomy. ${ }^{62}$ The congress was organized by the Russians, but Aleksander Lednicki, a Polish lawyer who belonged to All-Russian Congress of Lawyers, was the appointed mediator between the Polish and Russian groupings. He wielded considerable influence with Russian liberals, as well as Russian aristocrats and politicians. At that time, he had been working towards a Polish-Russian compact with the autonomy of the Kingdom in view. ${ }^{63}$ We can assume that the invitation to attend the Congress to Warsaw lawyers was issued thanks to Lednicki. ${ }^{64}$ It is unknown how long Patek and Lednicki had known each other and when their acquaintanceship started. However, we know that Patek often stayed at Lednicki's house in Moscow and took part in meetings with Russians. He maintained contact with Lednicki after the war. The Congress could not bring considerable changes for Polish lawyers but it proved to be an important meeting ground for Polish-Russian liberals. Additionally, there were numerous congresses of various occupational groupings in Russia. During

62 H. Kiepurska, Inteligencja zawodowa Warszawy, pp. 124-125. Kiepurska quotes a statement of a Polish lawyers published in "Czerwony Sztandar" in 1905: "The Bar in the Polish Kingdom forms a separate body, and therefore it cannot be part of the All-Russian Association of Lawyers. If necessary, it can enter into relations with the Russian Bar on the basis of equal rights. It is necessary to grant the Polish Kingdom legal and administrative autonomy based on a common, equal, direct and secret ballot of all Polish citizens. Representatives of the Polish Bar express a great deal of sympathy for the Russian Constitutional Movement. Its representatives will take part in further works of the Congress, if the autonomy of the Polish Kingdom is recognized."

63 Aleksander Lednicki (1866-1934) lived in Moscow until 1917, where he had his chambers. He was the President of the Polish Charity Society and the cofounder of the Polish Library, the Polish House, and the Lute and Falcon (Sokoły) societies in Moscow. He was also a member of the Russian Lawyers Council (1903-1917) and a member of the Progressive Democrat Party. In Russia, he entered the First Duma (parliament) as a member of the Democratic Constitutional Party. He cooperated with Aleksander Świętochowski in the Progressive-Democratic Association, and together they established the Polish Cultural Society in Warsaw. In 1914, Lednicki established the Polish Committee for War Victims in Moscow. Furthermore, Stanisław Patek, the Right Reverend Cieplak, Marian Zdziechowski, Jerzy Zdziechowski, Władysław Glinka, Władysław Sobański, Seweryn Czetwertyński, Adam Szelągowski, Maciej Radziwiłł, Leon Berenson, Józef Hłasko, Jerzy Kurnatowski, Archbishop Edward Rop and the Lutosławski brothers, held meetings at Lednicki's house in Moscow during World War I. In 1916, Lednicki was among the founders of the Russian Friends of Polish Independence Society in Petrograd (as St. Petersburg was renamed). Upon the fall of tsarist autocracy and the assumption of power in Russia by Lednicki's close collaborators, he became the President of the Polish Liquidation Committee for the Polish Kingdom in Petrograd where he resided since 1917. The Committee, composed of Poles and Russians, was to separate the Polish Kingdom from Russia. Pavel Miliukov, the Minister of Foreign Affairs for the Temporary Government, was Lednicki’s friend. More in: Z. Nagórski, Aleksander Lednicki, "Zeszyty Historyczne", 1962, pp. 27-66; L. Bazylow, Polacy w Petersburgu, Wrocław 1984; T. Stegner, op. cit.; A. Lednicki, Pamiętnik: 1914-1918, introduction and monograph Z. Koziński, Kraków 1994; W. Lednicki, Pamiętniki, vol. 1-2, London 1967, especially vol. 2, pp. 488-520.

64 This view is represented by H. Kiepurska, Inteligencja zawodowa Warszawy, p. 124; T. Stegner, op. cit., p. 138. 
that particular meeting, Polish liberals presented their programmes of autonomy for the Kingdom and gained support from Russian liberals. ${ }^{65}$

The meetings between Polish and Russian lawyers did not bring the expected results, but contacts with All-Russian Congress of Lawyers were maintained. The problem of the Kingdom's autonomy divided Russians, with many lawyers supporting the Polish demands. Polish lawyers were targeted on setting up their own professional organization albeit with a political aim. This goal was achieved during the Congress of representatives of the Polish legal community from both the Kingdom and the Empire (61 delegates) on 13 June 1905. The Polish Bar Association was created at that time. ${ }^{66}$ All Polish lawyers could join the Association, regardless of their place of residence (i.e. even those who practised in Russia). Therefore, people who had different views and who belonged to different groups and organizations created this professional and non-party union. Because of that, lawyers were divided into autonomous groups, associated with their place of work. That was how the Warsaw Bar Association arose.$^{67}$ Patek belonged to this Association, which was part of the Polish Bar Association. In the formal sense, it was an illegal organization.

A general political strike was staged in the Kingdom on 25 October 1905. Tsar Nicolas II issued what was referred to as a constitutional manifesto on 30 October although it made no reference to a constitution as such, but it did address civil rights issues such as freedom of conscience, freedom of speech, the right of gatherings and freedom of association. Demonstrators in Warsaw's Theatre Square demanded the release of political prisoners on 1 November. The Cossacks were sent into action in response. People were killed and wounded. Next day, in a gesture of protest, Warsaw lawyers failed to report for duty in courts and members of the Warsaw Bar Association sent a telegram to Witte, the Prime Minister. The telegram expressed their outrage at the excessive force of strength employed against the demonstrators. The situation in the Kingdom was extremely tense. There were numerous discussions and meetings. Almost every occupational group organized assemblies of their members. ${ }^{68}$ Warsaw lawyers organized an assembly in the premises of the Society of Technicians on 5-8 November. The daily "Kurjer Warszawski" reported: "Polish lawyers debated for over twenty hours. Please do not suspect me of exaggeration. The assembly started on Sunday at 11 p.m. After two hours of debate, the meeting

65 W. Lednicki wrote a lot about that in Pamiętniki, vol. 2, pp. 480-535.

66 Status Związku adwokatury polskiej, "Gazeta Sądowa Warszawska”, no. 49, 9 December 1905, p. 788. In the Statute of the Association, it was written: "1. The Association of the Polish Legal Community is to defend the rights of the Polish nation and the unification of the professional and social activities of Polish lawyers. 2. In order to achieve the above mentioned aims, the Association: a) will undertake all the necessary works and steps of a legal and social nature in an attempt to redeem, defend, restore and preserve the rights of the Polish nation..."

67 Zebranie ogólne związku warszawskiego adwokatury polskiej, "Gazeta Sądowa Warszawska”, no. 51, 23 December 1905, pp. 823-824. H. Cederbaum. wrote about different opinions on the form and scope of changes in the Kingdom and about the differences among lawyers in Zwiazki adwokackie, "Kurjer Warszawski", no. 354, 23 December 1905, p. 8.

68 Those meetings were described in "Kurjer Warszawski", nos. 307, 308 and 310 in 1905. 
was interrupted because the legal community in corpore, with only few exceptions, went to the national rally. Next day, on Monday at 5 p.m., the debate was resumed and lasted the whole night without a break until 5 a.m. Since not all items on the agenda had been aired, the gathering reconvened for the third time and was locked in discussion until midnight. The debates were tiring and people were dropping with exhaustion, but they stayed until the end. ${ }^{69}$ They discussed the possibility of a strike of the legal community, the introduction of the Polish language in court, and the autonomy of the Kingdom. The problem of whether the legal community should or should not join the strike was of true relevance to the way it functioned after the reform of the judiciary in 1876. Before that, the French system prevailed, in which each court case had to take place in the presence of lawyers. Their presence was no longer necessary after 1876 . Strike action taken by lawyers would not have stopped the machinery of justice, and cases would continue, thus they rejected this option in a ballot. However, the court activities of lawyers were suspended until a general assembly of barristers was convened. People were in favour of abolishing the death penalty and they sent delegates to St. Petersburg in order to talk with the Russian authorities. ${ }^{70}$ This delegation met Witte on 11 November. They were told that reforms in the Kingdom could be carried out once calm was restored. Martial law was still to remain in force and introduced throughout the whole Kingdom (as was already done on 10 November)..$^{71}$ The response and attitude of the Russian authorities had the effect of activating not just the Poles, but also Russian groupings that supported Polish demands. Halina Kiepurska took note of the fact that the representatives of lawyers of the older generation supported the strikes, issuing memoranda and attempting to talk with the Russian side. The younger generation, frequently connected with the PPS and the SDKPiL, opted for more radical forms of protest. ${ }^{72}$ It is not certain, but we can assume that Stanisław Patek was in the first group of lawyers, oriented towards dialogue with the Russians. The legal profession was however increasingly divided on the issue of reforms in the judiciary and in the Kingdom, on the forms of contacts with the Russian legal community, and accession or non-accession of the Polish Bar Association to the Federation of Associations of the Polish Kingdom.

Stanisław Patek was an active participant in all those events. His name frequently appeared in the press, informing about different meetings, organizing committees, and legal aid centres. Both his actions and those of others, that were engendered by the wave of revolutionary events in the Russian Empire, had no chance of success. Stanisław Patek's political views were quite moderate in that period. $\mathrm{He}$ wanted to cooperate with the Russian government in terms of political changes in

69 H. Cederbaum, Wiec Prawników, "Kurjer Warszawski”, no. 310, 9 November 1905, p. 5.

70 ibid.

71 Delegaci prawników polskich u hr. Wittego (Protokót) was signed by: Stanisław Leszczyński, Henryk Konic, Leon Papieski, Feliks Ochimowski, Tadeusz Strzembosz, "Kurjer Warszawski”, no. 314, 13 November 1905, p. 5.

72 Quoted after: H. Kiepurska, Adwokaci warszawscy, "Palestra”, 3(75), pp. 15-20. 
the Kingdom. It is difficult to say whether it was based on a realistic assessment of the political situation or the true position of a legalist. It seems that his contacts with Józef Piłsudski did not find reflection in his political activities. However, a far greater degree of radicalism was evident in his professional activities as a lawyer and his defence of prisoners. Stanisław Patek, together with Julian Krzycki and Leon Papieski, ran the Political Case Defence Group (in literature sometimes known as the Political Defendants' Group). The Group was established in December 1905 at the Bar Consultancy Association in cooperation with the Department of the Polish Bar Association.

Patek was also connected with the General Aid for Political Prisoners Fund which was set up on Maria Paszkowska's initiative (a PPS activist) in 1903. Stanisław Kruszewski and Maksymilian Zand also took part in the Fund's work. The General Fund was connected with the Red Cross Society (run by the SDKPiL) in June 1905 and together they created the Help for Political Prisoners Society (by the end of 1905 it had thirty lawyers among its members). ${ }^{73}$ In June 1906, due to the extension of the Fund's activities to helping deportees and their families who returned from exile, the Fund transformed itself into the Political Victims Help Society. Although the Russian authorities did not recognize this organization, it acted openly. Many organizations in the Kingdom functioned in this way. According to Sempołowska "it became semi-legal, i.e. not legalized, and had representatives, who maintained official contacts with the authorities for whom the existence of this organization was no secret." 74 It became one of the most important organizations in Patek's activities. It was mainly Patek (though Julian Krzycki as well) who offered legal aid to those who needed it. The Society's office was located in Patek's chambers at 25 Królewska Street. The history of the Society and Patek's activities were connected with the famous 'Patronage' - the Care for Prisoners in Warsaw Society which was organized in 1909 to help political prisoners and their families. ${ }^{75}$ Patek's activities provoked a sharp reaction and repressions from the Russian authorities. He was accused of having connections with the revolutionary movement and arrested by the Russian authorities on 10 February 1908 (he remained in custody until 5 March). Colonel Pavel Zawarzin, in a report to Skałon on 28 March 1908, wrote that brochures, socialist and revolutionary publications, and correspondence with representatives of those movements were found during Patek's house search. However, this Russian officer also mentioned that Patek was not in a revolutionary party, but only rendered legal

73 “Kurier Poranny", 1905, no. 304, p. 4.

74 S. Sempołowska, $W$ więzieniach, p. 95.

75 Zofia Zbyszewska described his history and activities in Ministerstwo Polskiej Biedy. Z dziejów Towarzystwa Opieki nad więźniami "Patronat" w Warszawie 1909-1944, Warsaw 1983. The author based her knowledge mainly on memoirs because of the lack of documents. She took the name of the Polish Ministry of Poverty from Leon Berenson. There were several such Patronages (as from the second half of the 19th century) in the Kingdom of Poland which were often run by women belonging to a society known as "Entuzjastki" (Female Enthusiasts). The Patronage received financial help from Geneva from the International Red Cross for political prisoners which was organized by Wiera Figner. 
services as defence counsel to its members. The Russian authorities wanted to exile Patek from the Kingdom but they were afraid of the reactions of Polish and Russian lawyers. Zawarzin wrote about Patek's solid position in those groupings and liberal circles. Furthermore, he admitted that Patek behaved loyally towards the authorities and did not evince politically seditious attitudes." ${ }^{36}$

After this incident, the tsarist authorities paid close attention to Patek's activities. Attempts were made to induce him to resign from his work as a lawyer. When that pressure failed to produce the desired results, the Judicial Chamber struck him off the list of active lawyers on 7 May 1911. As Zawarzina predicted, this led to protests of the Russian community. Zbigniew Landau wrote that Russian lawyers published "a ninety-page collection of documents entitled Delo prisjažnago poverennago Patka (St. Petersburg 1911), reporting the whole matter." 77 The Warsaw District Court decided to strike Patek off the list of sworn lawyers during its meeting on 17 December 1910. The Warsaw Judicial Chamber in a disciplinary lawsuit debarred Patek on 20 May 1911. Patek was accused of political activity and membership of "the Red Cross." ${ }^{78}$ Earlier, Patek had to face several disciplinary lawsuits. The constant pressure from St. Petersburg became very strong in 1910 and the Judicial Chamber had to give in. Furthermore, the lawyers, the defence counsels in political lawsuits were treated like Patek. Leon Wasilewski wrote: "The Tsar's counter-revolution is now taking its revenge on everybody who is considered to be inconvenient to the governmental authorities, even if there is no evidence of their political activities. A glaring act of such revenge is the act, just made, of debarring Patek, a prominent lawyer in Warsaw. Patek, a man far from any revolutionary activity, a man of progressive democrat persuasion, provoked the ire of the government because he courageously defended the victims of the vicious savagery of the "Okhrana" on numerous political trials."79

76 The Main Public Record Office, Warsaw Lawyer's Chamber of the Governor-General, file no. 3630, Zawarzin's report to Warsaw Governor-General Gieorgij Skałon.

77 Z. Landau, Patek Stanistaw, PSB, vol. 25, p. 322.

78 Wykreślenie adwokata przysięgłego Patka, "Gazeta Sądowa Warszawska”, no. 22, 3 June 1911, p. 332 .

79 L. Wasilewski, Sprawa p. Patka, "Przedświt”, no. 7/8, 1911, p. 425. 